\title{
Electrophoresis of Proteins of 3 Penicillium Species on Acrylamide Gels
}

\author{
By K. J. BENT* \\ Imperial Chemical Industries Ltd., Pharmaceuticals Division, Akers \\ Research Laboratories, Welwyn, Hertfordshire
}

(Accepted for publication 4 May 1967)

\begin{abstract}
S U M M A R Y
Soluble proteins extracted from mycelium of Penicillium griseofulvum were separated by acrylamide-gel electrophoresis. The pattern and overall intensity of the protein bands varied greatly with age of culture. A marked decrease in band intensity occurred at the time of exhaustion of the nitrogen source in shaken cultures, and at an earlier stage in static cultures; the total protein in whole or ultracentrifuged extracts did not decrease to the same extent. Changes in the pattern and intensity of protein bands during incubation occurred also in $P$. chrysogenum and $P$. frequentans. Mycelium of $P$. griseofulvum which was induced to sporulate in shaken culture yielded little protein as shown by electrophoresis at early stages of culture, in comparison with non-sporing mycelium. Each of these three Penicillium species could be distinguished by the protein pattern, which was reproducible and characteristic of the fungus at any particular stage of culture. The results indicate the need to determine the effects of age and conditions of culture when gel electrophoresis of mycelial proteins is used for taxonomic purposes.
\end{abstract}

\section{INTRODUCTION}

Gel electrophoresis is a valuable method for separating soluble protein fractions extracted from the mycelium of fungi and actinomycetes. Distinct and reproducible differences have been found between the protein patterns of related species and of strains within species (Chang, Srb \& Steward, 1962; Clare, I963; Durbin, I966; Gottlieb \& Hepden, I966; Clare \& Zentmyer, I966). Changes in the age or conditions of culture appeared to have no appreciable effects on the relative intensities or positions of the protein bands (Clare, I963; Durbin, 1966; Gottlieb \& Hepden, 1966; Clare \& Zentmyer, 1966). In the present investigation, however, the proteins of Penicillium spp. separated by electrophoresis were found to vary greatly according to the age and physiological condition of the mycelium.

\section{METHODS}

Organisms. The following fungi were used: Penicillium griseofulvum Dierckx (375); P. chrysogenum Thom (167); P. frequentans Westl. (733). The numbers refer to the culture collection of the Akers Research Laboratories.

Cultural methods. The fungi were grown from spore inocula, in shaken or in sta-

\footnotetext{
* Present address: Imperial Chemical Industries Ltd., Agricultural Division, Jealott's Hill Research Station, Bracknell, Berkshire.
} 
tionary flasks, on a liquid glucose + ammonium sulphate + salts medium. Details of the cultural methods have been published (Bent \& Morton, 1964).

Extraction and electrophoresis of mycelial proteins. Samples of mycelium were collected by filtration, washed twice with water and stored at $-15^{\circ}$. Samples from shaken cultures (about I g. fresh weight) were placed in $9 \mathrm{ml}$. of cold $0.067 \mathrm{M}$-phosphate buffer $\left(\mathrm{pH} 7{ }^{\circ} \mathrm{O}\right)$ and shaken at high speed with glass beads on a wrist-action shaker in a cold room $\left(3^{\circ}\right)$ for $30 \mathrm{~min}$. Mycelial felts from static cultures were first broken up in buffer with a blender for $2 \mathrm{~min}$. and then ground in a cooled glass tissue-grinder for 5 min.

The suspensions were centrifuged at $25,000 \mathrm{~g}$ for $30 \mathrm{~min}$. Volumes of supernatant fluid equivalent to $\mathrm{I} \cdot 25 \mathrm{mg}$. dry weight mycelium were submitted to disc electrophoresis on polyacrylamide gels. In general the procedure described by Ornstein \& Davis ( 1962) and by Davis (I964) was followed, but samples were applied in $25 \%(\mathrm{w} / \mathrm{v})$ sucrose solutions instead of in large-pore gels. Sometimes spacer gels were also omitted. The above methods were adopted largely for convenience, since no appreciable difference to the electrophoretic pattern was made by using different homogenisation techniques (grinding in a glass tissue-grinder, passage through a Hughes press, shaking with glass balls), by using different extraction fluids (water, phosphate buffer at $\mathrm{pH} 6.0$ or 7.0 , $0.25 \mathrm{M}$-sucrose in $\mathrm{pH} 7.0$ buffer), by the presence or absence of large-pore sample or spacer gels, by conducting electrophoresis at $3^{\circ}$ instead of at room temperature, by storing mycelium at $-15^{\circ}$ for 2 weeks, by drying mycelium with acetone or by successive centrifugation of $1000 \mathrm{~g}$ supernatant fluids at 25,000 and $100,000 \mathrm{~g}$. Electrophoresis patterns obtained with replicate portions of one protein extract, with replicate extracts from one culture, or with mycelial samples taken from separate but similar cultures of the same age grown on the same or on different occasions, were virtually identical when run in the same batch. Unpredictable minor variations in the relative mobility of bands sometimes occurred when one preparation was treated on different occasions under apparently the same conditions, although the overall pattern of bands was maintained. For this reason, samples were run in the same batch before detailed comparisons between different preparations were made.

Determination of protein. Total protein contents of mycelium and mycelial extracts were determined by the method of Lowry, Rosenbrough, Farr \& Randall (I95I), with bovine serum albumin (fraction V) as the standard.

The use of conventional methods (such as determination by the method of Lowry et al. or by measurement of $\alpha$-amino-nitrogen after acid hydrolysis) to determine total protein in the gels or in extracts therefrom was precluded by the occurrence of high blank values, presumably due to the peptide links in the polyacrylamide. The amount of protein in the gels was estimated by determining directly the intensity of the Amido Black staining. After removal of the spacer gel, each small-pore gel was trimmed beyond the electrophoretic front to a suitable length, inserted into a glass tube from which its end protruded slightly and placed in a $4 \mathrm{~cm}$. spectrophotometer cell so that its ends were just flattened against the walls of the cell. The cell was placed in a Unicam SP 500 spectrophotometer, with the gel aligned lengthwise in the light path, and the extinction at $600 \mathrm{~m} \mu$ was measured against a blank gel. Standard gels were prepared from bovine serum albumin (fraction V). Extinction was related linearly to the amount of albumin or mycelial extract applied to the gels; readings from replicate gels were within $3 \%$ of the mean values. 
RESULTS

The pattern and the overall quantity of soluble protein in electropherograms of extracts of Penicillium griseofulvum varied considerably during the course of shaken culture. The pattern shown in Pl. I, fig. 1 A, was typical of mycelium in the exponential phase of growth ( $18-27 \mathrm{hr}$ ), and in the original gels some I6 bands could readily be distinguished. Shortly before the exhaustion of the nitrogen source (the limiting nutrient), which occurred at $28 \cdot 5^{-29} \mathrm{hr}$, the pattern changed (Pl. I, fig. I B); several new bands appeared, and there were marked changes in the intensities of many of the bands shown by earlier samples.

During the subsequent period of nitrogen starvation there was a very marked and persistent decrease in the overall amount of protein appearing in the gels ( $\mathrm{Pl}$. I, fig. I C and D). Some bands decreased more than others, so that further changes in pattern could be distinguished. During this nitrogen-deficient stage of incubation, the hyphae continued to grow in length. When young $(24 \mathrm{hr})$ mycelium was removed from the culture medium and shaken in fresh medium from which the nitrogen source was omitted, a similar rapid and large decrease in overall band intensity and similar changes in pattern took place. More concentrated extracts of older mycelium were used in an attempt to increase the band intensities, so that the patterns could be compared more easily with those given by younger cultures. However, the results were unsatisfactory since the rate of protein migration from the stronger extracts was much slower; after prolonged electrophoresis the bands became diffuse and were obscured by heavy background staining.

A comparable sequence of changes in the soluble proteins of Penicillium griseofulvum occurred when the fungus was grown in static culture. In this type of culture, however, changes were detectable at a relatively early stage, when only half of the available nitrogen had been consumed (170 $\mu \mathrm{g} . \mathrm{N} / \mathrm{ml}$. remaining). Thus the gel shown in Pl. 1, fig. I F, representing mycelium grown in still culture for $50 \mathrm{hr}(130 \mu \mathrm{g} . \mathrm{N} / \mathrm{ml}$. remaining), had a pattern intermediate between those of Figs. I A and B, but closer to that of Fig. I B, which was derived from a shaken culture in which the nitrogen source was almost exhausted. At later stages of static culture there occurred a further general decrease in band intensity and also changes in pattern similar to those observed in the shaken cultures.

Gels were also prepared from shaken cultures of Penicillium griseofulvum growing in a medium prepared with a crude commercial glucose instead of reagent grade glucose. The crude glucose contained factors which promoted the sporulation of this fungus in shaken culture (Armstrong, England, Morton \& Webb, I963); Pl. I, fig. I E represents mycelium which was just starting to sporulate (the hyphae were highly branched and most of the tips bore incipient conidiophores). In general intensity of staining and in band pattern there was a resemblance to gels representing nitrogen-starved mycelium rather than to gels prepared from comparable young non-sporing cultures. This distinction between young mycelia of sporing and vegetative cultures was observed in several experiments. As the cultures aged, gels of sporing mycelium became in intensity and pattern more like those of non-sporing cultures of similar age.

The soluble proteins of Penicillium chrysogenum and $P$. frequentans (PI. I, fig. 2) changed with age of culture in much the same way as those of $P$. griseofulvum. Gels prepared from the three species at a particular time of incubation could be distinguished 
easily from each other. An independent observer was able to sort nine gels which represented these species at three times of incubation $(20,28,36 \mathrm{hr})$ correctly into groups representing each species, but only after the pattern of change, and particularly the general decrease in band intensity with age of culture, had been explained to him. When gels representing the middle stages of incubation were omitted, it was impossible to match the remaining gels.

The marked decrease in band intensity shown by gels prepared from older mycelium was unexpected, since earlier studies with Penicillium griseofulvum (Bent \& Morton, I964) had revealed that the total protein content of the mycelium underwent relatively small changes during shaken culture. The total protein contents of some electrophoresis gels were therefore compared with those of the mycelial extracts from which they were made (Table I). Although determinations in gels and in extracts were made by different methods (see above), the large differences in the values for protein obtained from gels and from corresponding mycelial extracts suggest that even at early times of incubation only a small proportion of the protein present in whole extracts, or in ultracentrifuged extracts, was represented by the stained bands in the gels. This proportion which moved electrophoretically decreased greatly during shaken or static cultures, especially after exhaustion of the nitrogen supply (Table I). Thus, under conditions of nitrogen starvation, there was a rapid and specific loss of those proteins which could enter gels and react with the Amido Black stain.

\section{Table I. Amounts of protein in extracts and electrophoresis gels prepared from mycelium of Penicillium griseofulvum at two stages of culture}

Protein is expressed as mg./g. mycelial dry weight. Nitrogen was exhausted from the medium at $28 \cdot 5^{-29} \mathrm{hr}$. (shaken culture) and 48-72 hr. (static culture). Extracts were centrifuged at $25,000 \mathrm{~g}$ for $30 \mathrm{~min}$., and at $100,000 \mathrm{~g}$ for $75 \mathrm{~min}$.

\begin{tabular}{|c|c|c|c|c|}
\hline Type of culture & Shaker & lture & Static & ture \\
\hline Age of culture & $24 \mathrm{hr}$ & $36 \mathrm{hr}$ & $48 \mathrm{hr}$ & $\mathrm{I} 20 \mathrm{hr}$ \\
\hline Ammonia- $\mathrm{N}$ in medium $(\mu \mathrm{g} . / \mathrm{ml})$. & 184 & 0 & 139 & o \\
\hline Total mycelial protein & 557 & 403 & - & $\rightarrow$ \\
\hline $\begin{array}{l}\text { Extracted protein in: } \\
\text { (a) whole extract } \\
\text { (b) } 25,000 \mathrm{~g} \text { supernatant fluid } \\
\text { (c) } 100,000 \mathrm{~g} \text { supernatant fluid }\end{array}$ & $\begin{array}{r}298 \\
159 \\
\end{array}$ & $\begin{array}{c}208 \\
83 \cdot 3 \\
-\end{array}$ & $\begin{array}{l}323 \\
146 \\
123\end{array}$ & $\begin{array}{l}271 \\
78 \cdot 9 \\
50 \cdot 0\end{array}$ \\
\hline $\begin{array}{l}\text { Proteins in gels from: } \\
\text { (a) whole extract } \\
\text { (b) } 25,000 \mathrm{~g} \text { supernatant fluid } \\
\text { (c) } 100,000 \mathrm{~g} \text { supernatant fluid }\end{array}$ & $\begin{array}{l}- \\
28 \cdot 4 \\
-\end{array}$ & I·O4 & $\begin{array}{l}27.3 \\
18.6 \\
17.5\end{array}$ & $\begin{array}{l}2 \cdot 07 \\
1 \cdot 60 \\
1 \cdot 4 I\end{array}$ \\
\hline
\end{tabular}

\section{DISCUSSION}

Changes in soluble protein content have been detected by various techniques in a wide range of organisms, including the fungi Blastocladiella emersonii (Cantino \& Goldstein, 1962) and Neurospora crassa (Williams \& Tatum, 1966), and reports of alterations in the amounts of individual enzymes in response to environmental factors are numerous. Nevertheless, in recent comparative studies of the soluble mycelial proteins of related species and strains of fungi the effects of the age and conditions of culture have appeared to be insignificant (see Introduction). The simplicity and sensitivity of the 
acrylamide-gel technique, coupled with the suitability of the gels for long-term storage, may lead to its widespread adoption for taxonomic and diagnostic work on the fungi. It is becoming increasingly evident that electrophoretic separation of mycelial proteins can provide a useful criterion for distinguishing the genotype, and the present study provides another example of this. The results make it clear, however, that standardisation of cultural conditions and attention to the physiological age of the organism must not be overlooked in this type of work.

A striking feature revealed in the present work was the rapid and selective decrease in those proteins that migrated electrophoretically, which occurred in shaken cultures when the external supply of nitrogen was exhausted or when mycelium was transferred to nitrogen-deficient medium. In static cultures similar changes occurred at a relatively early stage, well before the nitrogen supply was used up. This probably reflected the morphological differences between the two types of culture. In shaken cultures the fungi grew as dispersed suspensions of hyphae which were in direct contact with the medium, whereas in static cultures the mycelia developed as surface felts, of which large proportions must have been relatively remote from the nutrient supply.

Submerged mycelium growing on a supplemented medium which induced sporulation gave electrophoretic patterns which resembled those of nitrogen-starved mycelium. In the absence of specific nutritional factors for sporulation, such as those provided here, nitrogen starvation is one essential condition of sporulation of this organism in submerged culture (Morton, England \& Towler, 1958). The present results suggest that the factors in crude glucose may induce some of the metabolic effects normally brought about by nitrogen starvation, in young mycelium growing in the presence of assimilable nitrogen. The occurrence of a relatively low overall nitrogen content has been reported as another feature in common between young sporing mycelium and nitrogen-starved vegetative mycelium of Penicillium griseofulvum (Bent \& Morton, 1964). Protein turnover at a high rate has been detected in the mycelium of $P$. griseofulvum under conditions of nitrogen deficiency (Bent, I964), and it is possible that those proteins which appeared in the acrylamide gels were particularly liable to degradation and were not replaced by re-synthesis. Alternatively, such proteins may have aggregated or become bound into structures which were too large or carried an insufficient charge to be attracted into the gels, or which were not extractable from the mycelium. An apparent loss of the ethanol-soluble protein in Escherichia coli which occurred at the onset of sulphur starvation was shown to result from its interaction with intracellular polymetaphosphate that accumulated under this condition (Pine 1963) and not from its utilisation as a reserve material as first thought. Further investigations into the associational state of the mycelial proteins, and into the changes in the amounts and activities of specific enzyme proteins are warranted.

I wish to thank Mr D. H. W. Scott for his skilled technical assistance.

REFERENCES

Armstrong, J. J., England, D. J. F., Morton, A. G. \& Webb, J. A. (1963). Stimulation of sporulation in Penicillium by anhydroglucose. Nature, Lond. 197, 723 .

BENT, K. J. (1964). Significance of the amino acid pool in nitrogen metabolism of Penicillium griseofulvum. Biochem. J. 92, 280 . 
Bent, K. J. \& Morton, A. G. (1964). Amino acid composition of fungi during development in submerged culture. Biochem. J. 92, 260.

Cantino, E. C. \& Goldstein, A. (I962). Protein changes during morphological differentiation and its reversal in synchronized single generations of Blastocladiella emersonii. Am. J. Bot. 49, 642 .

Chang, L. O., SRb, A. M. \& STEWARd, F. C. (1962). Electrophoretic separations of the soluble proteins of Neurospora. Nature, Lond. $\mathbf{1 9 3}, 756$.

Clare, B. G. (1963). Starch-gel electrophoresis of proteins as an aid in identifying fungi. Nature, Lond. 200, 803 .

Clare, B. G. \& Zentmyer, G. A. (1966). Starch gel electrophoresis of proteins from species of Phytophthora. Phytopathology 56, 1334.

Davis, B. J. (1964). Disc electrophoresis II. Method and application to human serum proteins. Ann. N.Y. Acad. Sci. 121, Art. 2, 402.

Durbin, R. D. (I966). Comparative gel-electrophoretic investigation of the protein patterns of Septoria species. Nature, Lond. 210, I 186.

Gottlieb, D. \& Hepden, P. M. (I966). The electrophoretic movement of proteins from various Streptomyces species as a taxonomic criterion. J. gen. Microbiol. 44, 95.

Lowry, O. H., Rosenbrough, N. J., Farr, A. L. \& Randall, R. J. (I95I). Protein measurement with the Folin phenol reagent. J. biol. Chem. r93, 265.

Morton, A. G., England, D. J. F. \& Towler, D. A. (1958). The physiology of sporulation in Penicillium griseofulvum Dierckx. Trans. Br. mycol. Soc. 4I, 39.

Ornstein, L. \& Davis, B. J. (1962). Disc Electrophoresis. Preprinted by Distillation Products Industries, Eastman Kodak Co.

Pine, M. J. (I963). Alcohol-soluble protein of microorganisms. J. Bact. 85, $30 \mathrm{I}$.

Williams, C. A. \& TAтUM, E. C. (1966). Immunoelectrophoretic analysis of cytoplasmic proteins of Neurospora crassa. J. gen. Microbiol. 44, 59.

\section{EXPLANATION OF PLATE}

Fig. I. Soluble mycelial proteins of Penicillium griseofulvum. A, B, C and D, from shaken cultures at $22,28,33$ and $36 \mathrm{hr}$ respectively after inoculation. E, from a $22 \mathrm{hr}$ shaken culture induced to sporulate by factors in crude glucose. $F$, from a $50 \mathrm{hr}$ static culture.

Fig. 2. Soluble mycelial proteins of Penicillium chrysogenum (A, B, C) and P. frequentans (D, E, F), from shaken cultures at $22(\mathrm{~A}, \mathrm{D}), 28(\mathrm{~B}, \mathrm{E})$ and $36(\mathrm{C}, \mathrm{F}) \mathrm{hr}$ after inoculation. 
Journal of General Microbiologl', I'ol. 49, No. 2

Plate I
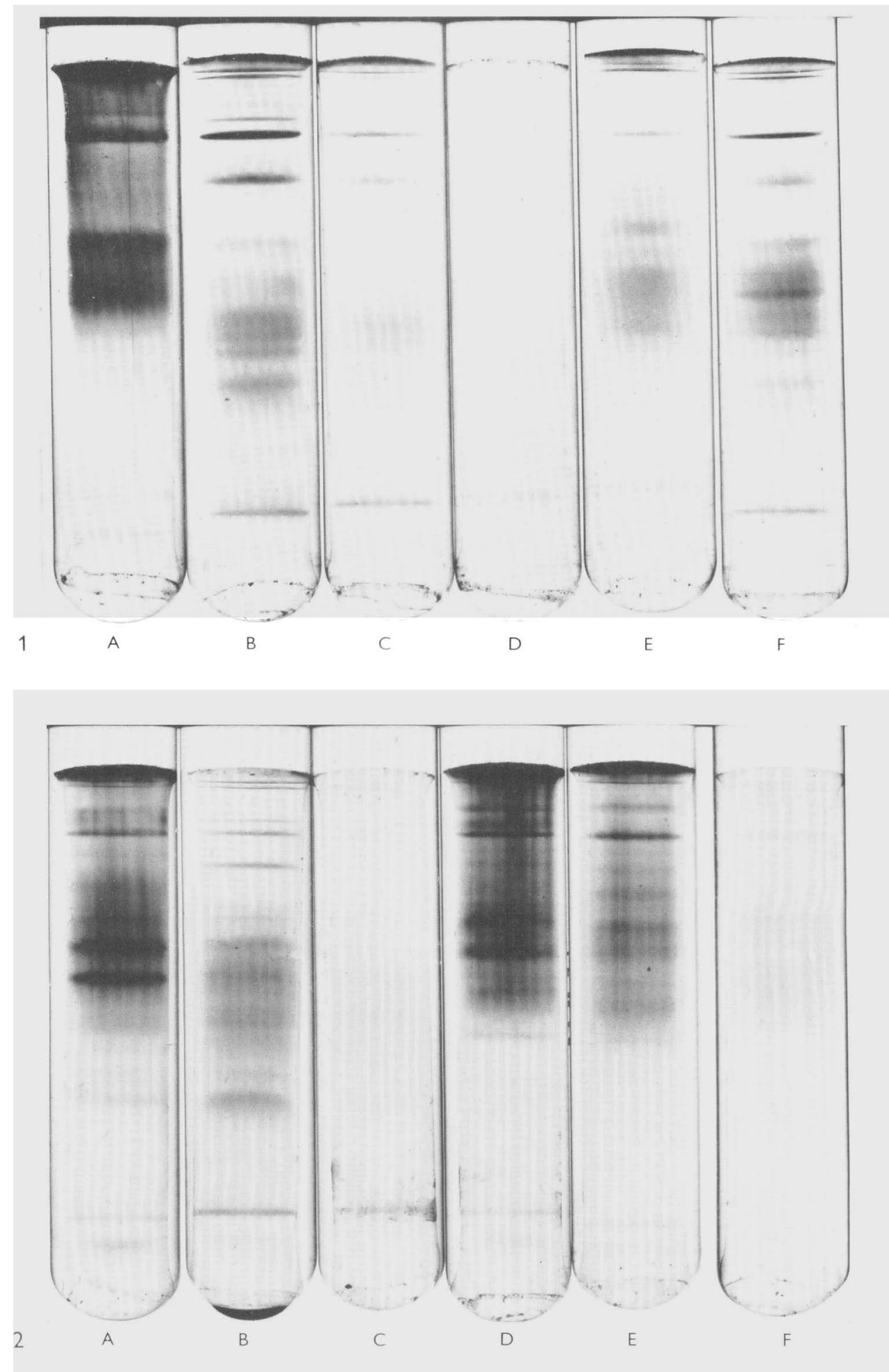

k. I. BI.NT 